p 775. (C) The Author(s), 2021. Published by Cambridge University Press on behalf of Royal Aeronautical Society. doi:10.1017/aer.2021.12

\title{
A non-iterative design for aileron to rudder interconnect gain - CORRIGENDUM
}

\section{J. Myala, V.V. Patel and G.K. Singh}

doi:10.1017/aer.2020.131, first published online 9 December 2020.

The original published version of this article included incorrect author affiliation details.

The incorrect version has been replaced and the authors apologise for any inconvenience caused.

\section{REFERENCE}

Myala, J., Patel, V. and Singh, G. A non-iterative design for aileron to rudder interconnect gain, The Aeronautical Journal, 2020, 1-12. 